\title{
Adiponectin mediates an antiproliferative response in human MDA-MB 231 breast cancer cells
}

\author{
ESTHER DOS SANTOS, DELPHINE BENAITREAU, MARIE-NOËLLE DIEUDONNE, \\ MARIE-CHRISTINE LENEVEU, VALÉRIE SERAZIN, YVES GIUDICELLI and RENÉ PECQUERY \\ Université Versailles-St Quentin, Service de Biochimie et Biologie Moléculaire, UPRES-EA 2493, \\ Faculté de Médecine Paris-Ile de France Ouest, Centre Hospitalier de Poissy, 78303 Poissy Cedex, France
}

Received January 14, 2008; Accepted February 28, 2008

DOI: $10.3892 /$ or_00000098

\begin{abstract}
Numerous epidemiological studies have documented that obesity is a risk factor for breast cancer especially in postmenopausal women. However, the molecular basis of this association is not well known. In contrast to leptin, plasma levels of adiponectin, another major adipokine, are decreased in obese subjects. Therefore, we and others hypothesized that adiponectin may be a paracrine factor negatively controlling mammary tumor development. We recently demonstrated growth inhibition of the estrogen-sensitive breast cancer MCF-7 cell line by adiponectin. The purpose of the present study was to determine whether this anti-proliferative effect of adiponectin also applies to the MDA-MB 231 estrogeninsensitive breast epithelial cancer cell line. Our results demonstrate that i) the adiponectin-specific receptors AdipoR1 and R2 are expressed in these cells, and ii) the subphysiological concentrations of recombinant adiponectin inhibit MDA-MB 231 cell growth and concomitantly enhance the expression of Bax and p53, two pro-apoptotic genes. Moreover, the invalidation of AdipoR1 and R2 mRNA experiments demonstrated that the anti-proliferative and proapoptotic effects of adiponectin were partially mediated via AdipoR1 and R2. We describe, for the first time, that AdipoR mRNA expression was down-regulated by adiponectin and leptin in MDA-MB 231 cells. Taken altogether, these results strongly suggest that the two adipokines should be considered as i) additional factors of breast cancer risk, and ii) may therefore be potential targets in breast cancer therapy.
\end{abstract}

\section{Introduction}

It is well established that the risk of developing breast cancer is greater in post-menopausal women with upper body fat predominance than post-menopausal women with a normal

Correspondence to: Dr Yves Giudicelli, Service de Biologie Moléculaire, Centre Hospitalier, 78303 Poissy Cedex, France E-mail: biochip@ wanadoo.fr

Key words: adiponectin, adiponectin receptors, MDA-MB 231, proliferation, apoptosis weight $(1,2)$. Although the biological mechanisms underlying this relationship between central obesity and breast cancer remain obscure, increasing evidence suggests that the adipose tissue of the mammary gland may play important roles in regulating cancer cell development (3). Besides estrogens, adipose tissue elicits significant endocrine functions, secreting a variety of bioactive peptides termed adipokines such as IGF-1, leptin and adiponectin (4,5). In obesity, altered adipokine secretion appears to contribute to an increased cancer risk. For example, leptin whose secretion is increased in obese patients promotes proliferation and suppresses apoptosis of different human breast epithelial cancer cell lines (6-8).

Adiponectin, a $30 \mathrm{kDa}$ adipokine, circulates at relatively high concentrations in human plasma. In contrast to other adipokines, adiponectin levels are inversely correlated with central fat accumulation $(9,10)$. Moreover, adiponectin improves insulin resistance and elicits anti-atherogenic and anti-inflammatory properties (11). Two types of adiponectin receptors (AdipoR1 and R2) have been described, both of which transduce an adiponectin signal via stimulation of the AMP- and MAP kinases, and PPAR $\alpha$ signaling pathways (12-14). AdipoR1 is ubiquitously expressed and displays a high-affinity for globular adiponectin whereas AdipoR2 is predominantly expressed in the liver and has a higher affinity for full-length adiponectin (12).

In addition to its role in energy homeostasis, adiponectin exerts a protective action against cancer development. Circulating adiponectin levels are inversely correlated with an increased risk of gastric, prostate and breast cancers (15-17). In breast cancer, an inverse correlation was found between plasma adiponectin levels and the histological grade of the tumor (18). Different in vitro studies also reported that adiponectin reduces cell proliferation and promotes apoptosis of the human non-aggressive estrogen-responsive breast cancer cells, MCF-7 $(7,19,20)$. We recently showed that a simultaneous exposure of these cells to adiponectin and $17 ß$-estradiol results in the total abolition of the mitogenic effect of 17ß-estradiol (20).

The aim of the present study was to determine whether adiponectin and its receptors are involved in the molecular mechanisms linking obesity and estrogen-independent breast cancer development. We thus tested in vitro the effects of this adipokine on the growth and apoptosis processes of the MDA-MB 231 breast cancer cell line. 


\section{Materials and methods}

Materials. Recombinant human adiponectin and leptin were provided by R\&D Systems Europe Ltd. (Abingdon, UK), Superscript II Rnase H-RT by Gibco BRL (Grand Island, NY, USA), Taq polymerase and RNA guard by Pharmacia Biotechnology (Uppsala, Sweden). The in situ cell death detection kit was from Roche Molecular Biochemicals (Mannheim, Germany). $\left[{ }^{3} \mathrm{H}\right]$-thymidine was from Amersham.

Cell culture. The human breast cancer cells, MDA-MB 231, were obtained from the American Type Collection of Cell Collection (via Salisbury, UK). These cells were maintained in phenol red-free RPMI medium with $2 \%$ Hepes and $1 \%$ glutamin, $10 \%$ fetal calf serum (FCS), streptomycin $(0.1 \mathrm{mg} /$ $\mathrm{ml})$ and penicillin $(100 \mathrm{U} / \mathrm{ml})$ at $37^{\circ} \mathrm{C}$ in a $5 \% \mathrm{CO}_{2}$ atmosphere. The culture medium was removed $24 \mathrm{~h}$ later and replaced by phenol red-free RPMI supplemented with 5\% charcoalstripped FCS until the starting assays.

$\left[{ }^{3} H\right]$-thymidine incorporation. MDA-MB 231 cells were suspended in 24-well plates in RPMI supplemented with $10 \%$ FCS. During the exponential phase of growth, the culture medium was replaced by RPMI containing $5 \%$ charcoal-stripped FCS for $48 \mathrm{~h}$. The cells were exposed to various concentrations of human recombinant adiponectin $(5-500 \mathrm{ng} / \mathrm{ml})$ for $24 \mathrm{~h}$. For the final six hours, $\left[{ }^{3} \mathrm{H}\right]$-thymidine $(1 \mathrm{mCi} / \mathrm{ml})$ was added to the culture medium and radioactivity was then counted.

Cell counting. The experimental design used was the one described above except that the adiponectin concentrations tested were $25 \mathrm{ng} / \mathrm{ml}$. Cells were counted in a hemocytometer.

Apoptosis assay. After a $48 \mathrm{~h}$ incubation in RPMI supplemented with $5 \%$ charcoal-stripped FCS, cells were cultured in the presence of adiponectin (25 and $250 \mathrm{ng} / \mathrm{ml}$ ) for $96 \mathrm{~h}$. The validity of our experimental culture conditions was warranted by the well established pro-apoptotic response of MDA-MB 231 cells to camptothecin $(6 \mu \mathrm{M})(21)$.

Attached and floating cells were fixed in $70 \%$ ethanol at $-20^{\circ} \mathrm{C}$ overnight and then labeled for DNA fragmentation by TUNEL (Terminal deoxynucleotidyl-transferase-mediated dUTP nick end-labeling). The apoptotic index was calculated after counting a minimum of 5000 events by flow cytometry using an EPICS flow cytometer (Coulter Electronics, Miami, FL, USA).

AdipoR protein expression. Total extracts were resolved by SDS-PAGE (10\% acrylamide), transferred to PVDF membrane and blocked in buffer A $(20 \mathrm{mM}$ Tris- $\mathrm{HCl}, 137 \mathrm{mM}$ $\mathrm{NaCl}, 0.1 \%$ Tween 20) containing $2.5 \%$ gelatin for $2 \mathrm{~h}$. PVDF membranes were incubated overnight at room temperature with rabbit polyclonal anti-AdipoR1 antibody (1:200 dilution, Santa Cruz Biotechnology, sc-46749) or antiAdipoR2 antibody (1:200 dilution, Santa Cruz Biotechnology, sc-46756) in buffer A containing 2.5\% gelatin. After washing, the membranes were incubated with the secondary antiserum coupled to peroxidase $(1: 10000$ dilution in TBS-T) for $1 \mathrm{~h}$. The membranes were then incubated with the enhanced chemiluminescence detection system and exposed to X-ray film.

The protein concentration was measured according to Bradford (22) with BSA as the standard.

Quantitative RT-PCR. Total RNA $(0.5 \mu \mathrm{g})$ was reverse transcribed as previously described (23). Quantitative PCR was performed using a LightCycler ${ }^{\circledR}$ instrument (Roche Diagnostics) and primer sets as previously described in (9). The second derivative maximum method was used to automatically determine the $\mathrm{Cp}$ for the individual samples. For each sample, the concentration ratio (target/TBP gene, used as an internal standard) was calculated using the Roche software. Fold changes in expression were determined by calculating the normalized ratio which corresponds to concentration of the calibrator situation (without effector)/ concentration of unknown situation (with effector) (relative quantification).

RNA interference for AdipoR. Two pairs of small-interfering RNAs (siRNAs) corresponding to different regions of each receptor gene were chemically synthesized by Qiagen. The sequences of the sense siRNAs were: for human AdipoR1: AAG GAC AAC GAC TAT CTG CTA and CTG GCT AAA GGA CAA CGA CTA and for human AdipoR2: ACC AAT TTA AGT GAA CAT TTA and CGG CTC TCC TTG AAT AAG AAA. A fluorescently labeled, non-silencing control siRNA was useful for the optimization of transfection conditions and as a control for non-specific silencing effects. A positive control, consisting of a siRNA directed against human MAP kinase RNA sequence, was used concomitantly in order to ensure that optimal conditions were maintained and confirm experimental results. For the knockdown experiments, MDA-MB 231 cells were plated in 12-well dishes at $1 \times 10^{5}$ cells/well and cultured for $24 \mathrm{~h}$ in medium without antibiotics. Cells were transfected with siRNAs (1 or $5 \mathrm{nM} /$ well) using a HiPerfect transfection reagent (Qiagen) according to the manufacturer's instructions. After $72 \mathrm{~h}$ of culture, the $\left[{ }^{3} \mathrm{H}\right]$-thymidine incorporation or mRNA expression analyses were realized as described above.

Statistical analysis. All values were expressed as means \pm SEM of 4-8 separate experiments, and statistical analysis was performed using the non-parametric paired Wilcoxon test.

\section{Results}

AdipoR expression and regulation by various cytokines. Using RT-PCR analysis, we found that the two adiponectin receptor AdipoR1 and R2 mRNAs are expressed in MDA-MB 231 cells (Fig. 1A). Moreover, AdipoR mRNA expression was comparable with that observed in another mammary epithelial cancer cell line, the MCF-7 cells used here as a positive control. Notably, in MDA-MB 231 cells, AdipoR1 mRNA was predominantly expressed ( 10 -fold higher) compared to AdipoR2 mRNA. Western blot analysis confirmed the presence of the two receptors in MDA-MB 231 cells (Fig. 1B).

Otherwise, exposure of these cells to recombinant adiponectin $(25 \mathrm{ng} / \mathrm{ml})$ resulted in a rapid $(4 \mathrm{~h})$ down-regulation of 
A

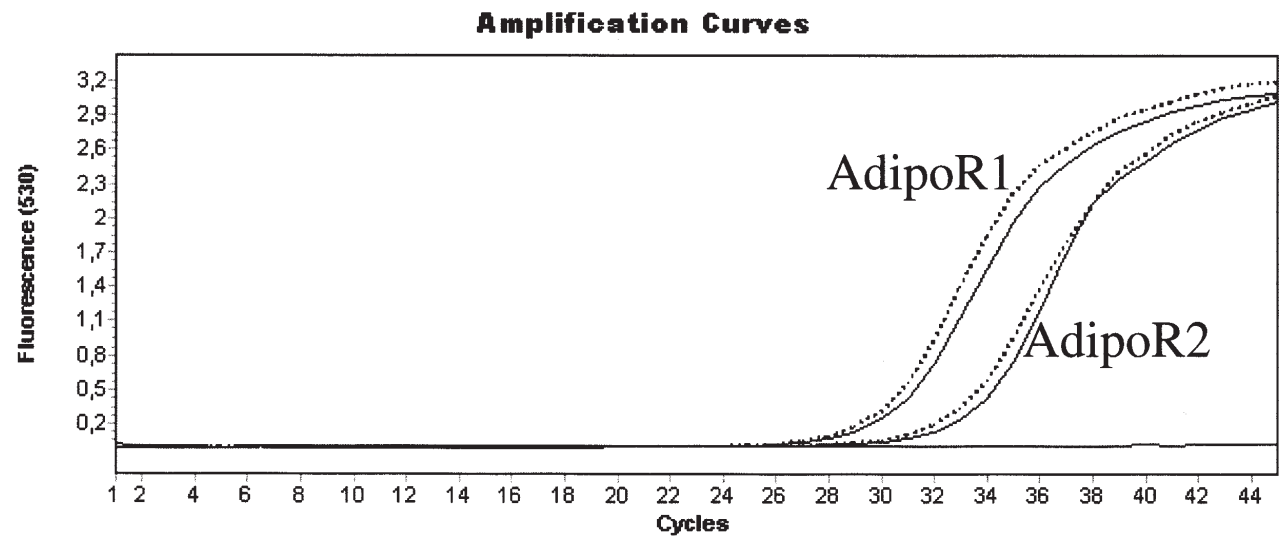

..... MCF7

B

\section{AdipoR1}

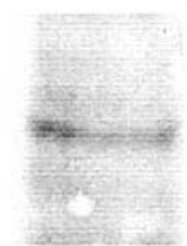

MCF-7

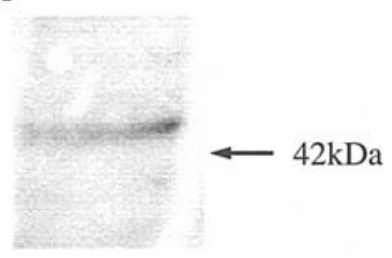

MDA

MDA MB-231

Figure 1. AdipoR expression in MDA-MB 231 cells. (A) AdipoR1 and R2 mRNA expression. Total RNA was extracted from MDA-MB 231 and MCF-7 cells and analyzed by quantitative RT-PCR. This figure shows representative amplification plots. (B) AdipoR1 and R2 protein expression. Cell lysates (100 $\mu \mathrm{g}$ ) were subjected to Western blot analysis using anti-AdipoR1 or anti-AdipoR2 antibody. One representative experiment of three is shown.

A

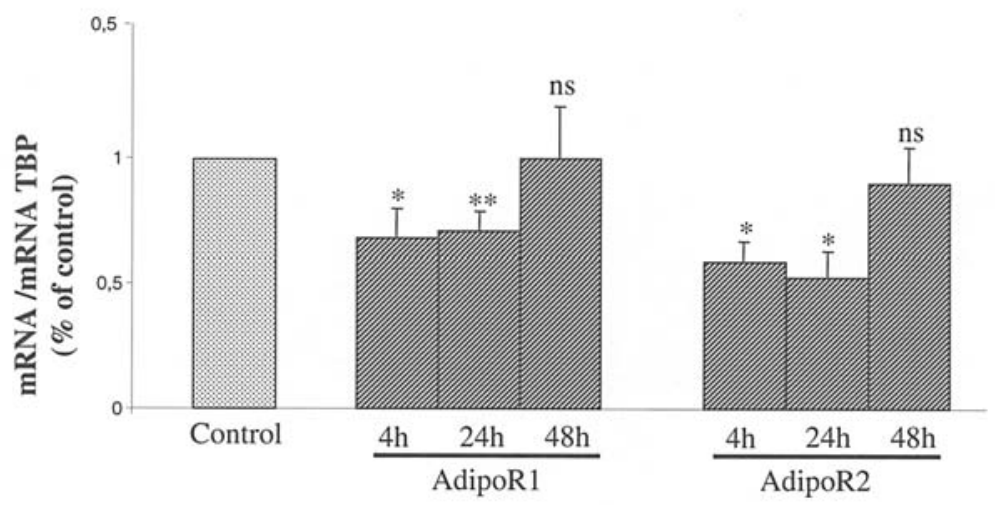

$\mathbf{B}$

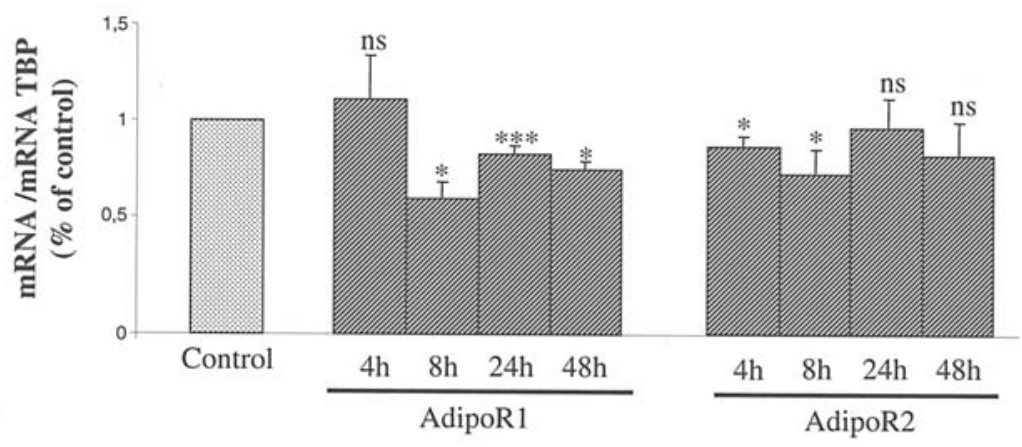

Figure 2. AdipoR mRNA regulation by adipokines in MDA-MB 231 cells. (A) AdipoR1 and R2 mRNA regulation by adiponectin. Cells were exposed to $25 \mathrm{ng} / \mathrm{ml}$ human recombinant adiponectin for different times as indicated in the figure. Total RNA was extracted and analyzed by RT-PCR. The values are the mean \pm SEM obtained from 5-8 separate experiments and are expressed as percentages of the control value (without adiponectin); ${ }^{*} \mathrm{p}<0.05$ and ${ }^{* *} \mathrm{p}<0.03$; ns, non-significant Wilcoxon test. (B) AdipoR1 and R2 mRNA regulation by leptin. Cells were exposed to $20 \mathrm{nM}$ human recombinant leptin for different times. Total RNA was extracted and analyzed by RT-PCR. The values are the mean \pm SEM obtained from 5-8 separate experiments and are expressed as percentages of the control value; ${ }^{*} \mathrm{p}<0.05$ and $^{* * *} \mathrm{p}<0.01 ; \mathrm{ns}$, non-significant, Wilcoxon test. 
$\mathbf{A}$

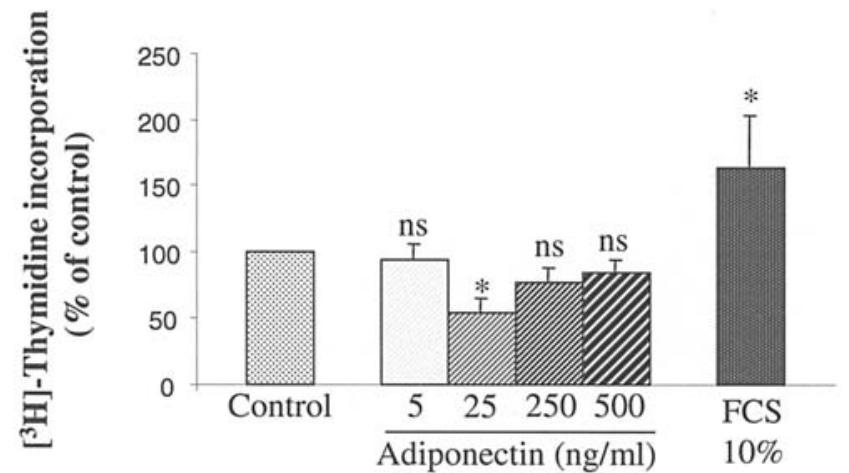

B

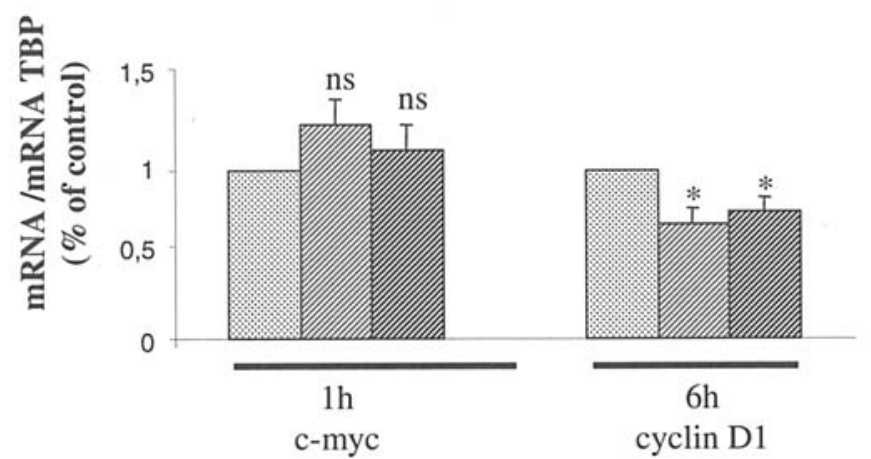

Control

Adiponectin $25 \mathrm{ng} / \mathrm{ml}$

Adiponectin $250 \mathrm{ng} / \mathrm{ml}$

Figure 3. Effects of adiponectin on MDA-MB 231 cell proliferation. (A) Effects of adiponectin on DNA synthesis. Cells were exposed to different concentrations $(5-500 \mathrm{ng} / \mathrm{ml})$ of human recombinant adiponectin in the presence of $\left[{ }^{3} \mathrm{H}\right]$-thymidine as described in Materials and methods. Results are the means \pm SEM of 5-8 experiments and are normalized as percentages of the control value; ${ }^{*}$ p $<0.05$; ns, non-significant Wilcoxon test. (B) Effects of adiponectin on cyclin D1 and c-myc mRNA expression. Cells were incubated during 1 or $6 \mathrm{~h}$ in the presence or absence of adiponectin (25 or $250 \mathrm{ng} / \mathrm{ml})$ for c-myc and cyclin D1 expression, respectively. Total RNA was extracted and analyzed by RT-PCR. Results are the means \pm SEM of eight experiments and are expressed as a percentage of the control; ${ }^{*} \mathrm{p}<0.05$; ns, non significant, Wilcoxon test.

the two AdipoR mRNA expression $(-32 \pm 12$ and $-41 \pm 8 \%$ for AdipoR1 and R2, respectively) which still persisted after $24 \mathrm{~h}$ (Fig. 2A).

The regulation of AdipoR expression by leptin, another cytokine involved in breast tumorigenesis (24), was studied in MDA-MB 231 breast cancer cells. As shown in Fig. 2B, leptin $(20 \mathrm{nM})$ significantly reduced the expression of AdipoR mRNAs. This effect was rapid for AdipoR1 and R2 $(-37 \pm 8$ and $-25 \pm 12 \%$, respectively, after $8 \mathrm{~h}$ of exposure) and persists until $48 \mathrm{~h}$ for AdipoR1.

Cell proliferation. Fig. 3A shows that adiponectin at $25 \mathrm{ng} / \mathrm{ml}$ significantly reduced $\left[{ }^{3} \mathrm{H}\right]$-thymidine incorporation $(-47 \pm 12 \%)$ in MDA-MB 231 cells. Under the same experimental conditions, $10 \%$ FCS was used as a control and induced a $1.6 \pm 0.4$-fold increase in $\left[{ }^{3} \mathrm{H}\right]$-thymidine incorporation. The anti-proliferative action of adiponectin was also confirmed by direct MDA-MB 231 cell counting $(-43.5 \pm 4.8 \%)$.

Expression of some cell cycle regulatory genes. C-myc and cyclin D1, two critical mediators of the cell cycle G1-S transition are convergent targets of mitogenic agents in breast cancer cells $(25,26)$. We thus investigated, by RTPCR, the influence of adiponectin on the expression of these two genes. As shown in Fig. 3B, cell exposure to adiponectin ( 25 and $250 \mathrm{ng} / \mathrm{ml}$ ) decreased by $\sim 30 \%$ cyclin D1 mRNA expression but did not affect the c-myc mRNA expression.
Cell apoptosis. Using quantitative RT-PCR analysis, we studied the influence of adiponectin on the expression of two pro-apoptotic genes (Bax and p53) and of one anti-apoptotic gene $(\mathrm{Bcl} 2)$ in MDA-MB 231 cells.

As shown in Fig. 4A, cell exposure to adiponectin at $250 \mathrm{ng} / \mathrm{ml}$ for $24 \mathrm{~h}$ resulted in a significant stimulation of the Bax and p53 mRNA expression (2.5 \pm 1.2 -fold change and $4.1 \pm 1.5$-fold change, respectively). Under the same experimental conditions $(24 \mathrm{~h})$ and for comparison, camptothecin (an inhibitor of topoisomerases) was used as a positive control and enhanced (1.7 \pm 0.2 -fold change) p53 mRNA expression. As shown in Fig. 4A, the anti-apoptotic gene, $\mathrm{Bcl} 2$, also appears to be a target for adiponectin as after $24 \mathrm{~h}$ of exposure, a $-55 \pm 8 \%$ reduction of $\mathrm{Bcl} 2$ mRNA was observed.

Concomitantly, we tested the final step of apoptosis by using TUNEL analysis to determine the percentage of labeled apoptotic nuclei (Fig. 4B). Surprisingly, DNA fragmentation in MDA-MB 231 cells was apparently not affected by adiponectin whatever the concentration of hormone tested. Under the same conditions, however, camptothecin, an apoptotic agent used as a control, significantly increased the population of apoptotic cells (2.8 \pm 0.3 -fold change).

AdipoR invalidation. In these experiments, we tested two different siRNA duplex for each receptor and finally chose those which induced a decrease of 79 and $76 \%$ in AdipoR 1 and R2 expression, respectively, after a transfection of $72 \mathrm{~h}$ (Fig. 5A). Furthermore, as shown in Fig. 5B, the suppression 
A

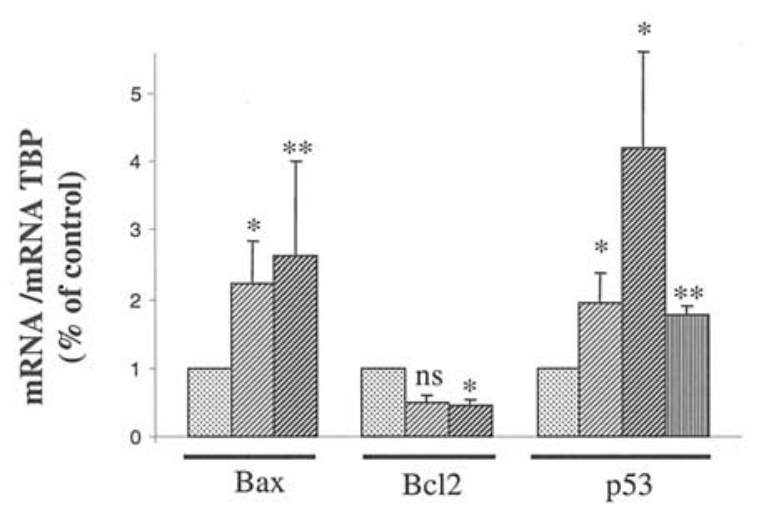

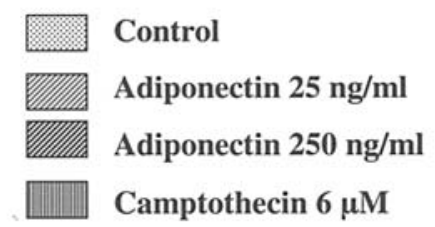

B
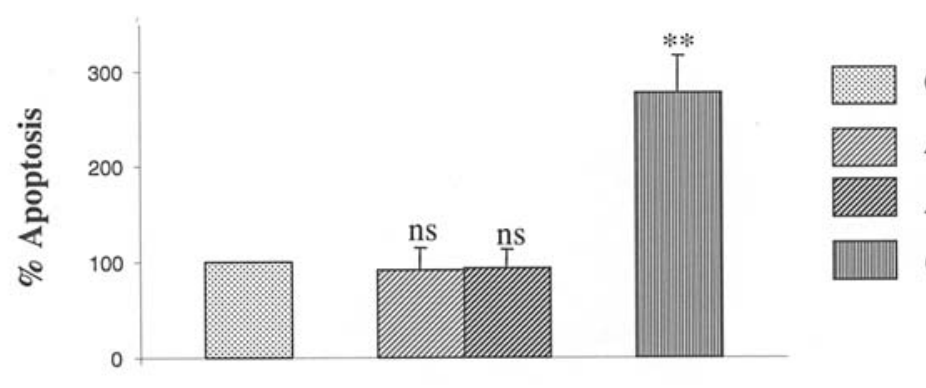

\section{Control}

Adiponectin 25 ng/ml

Adiponectin $250 \mathrm{ng} / \mathrm{ml}$

Camptothecin $6 \mu \mathrm{M}$

Figure 4. Effects of adiponectin on MDA-MB 231 cell apoptosis. (A) Effects of adiponectin on p53, Bax and Bcl2 mRNA expression. Cells were cultured for $24 \mathrm{~h}$ in the presence or absence of adiponectin $(25$ and $250 \mathrm{ng} / \mathrm{ml})$ or camptothecin $(6 \mu \mathrm{M})$. Total RNA was extracted and analyzed by RT-PCR. Results are the means \pm SEM of 5-8 experiments and are expressed as a percentage of the control; ${ }^{*} \mathrm{p}<0.05$ and ${ }^{* *}$ p $<0.03$; ns, non-significant Wilcoxon test. (B) Effects of adiponectin on DNA fragmentation. Cells were cultured for four days in the presence or absence of adiponectin ( $25 \mathrm{or} 250 \mathrm{ng} / \mathrm{ml})$ or camptothecin (6 $\mu \mathrm{M})$. Cells were then analyzed by TUNEL staining and flow cytometry. Results are expressed as a percentage of the control. Each bar represents the mean \pm SEM of four separate experiment; ${ }^{* *} \mathrm{p}<0.01$; ns, non-significant, Wilcoxon test.

of AdipoR1 and R2 with siRNA inhibited the increasing Bax mRNA expression by adiponectin. These data indicated that the adiponectin-induced pro-apoptotic gene expression is mediated by AdipoR in MDA-MB 231 cells. In constrast, under these conditions, transfected MDA-MB 231 cells failed to elicit any significant change in the ability of adiponectin to reduce DNA synthesis after adiponectin treatment (Fig. 5C).

\section{Discussion}

Different in vitro studies recently described the direct antiproliferative effects of adiponectin on the breast epithelial cancer MCF-7 cell line $(20,27,28)$. However, the molecular mechanisms explaining these effects have yet to be fully elucidated. As most of these studies were conducted in ERpositive breast cancer cell lines, herein we provide evidence that adiponectin also inhibits the proliferation of the ERnegative breast cancer MDA-MB 231 cells. This finding suggests that adiponectin may exert an estrogen-independent protective effect in vivo against breast cancer development and that the cell growth actions of estrogens and adiponectin involve different transduction pathways.

For this purpose, we verified the presence of the two AdipoR isoform (AdipoR1 and R2) mRNA and protein levels in MDA-MB 231 cells. As with human adipose tissue and T47D mammary cancer cells $(28,29)$, MDA-MB 231 cells predominantly express the AdipoR1 isoform which is consistent with the concept that AdipoR1 is ubiquitously expressed, whereas AdipoR2 is more restricted to the liver and skeletal muscle (12). In MDA-MB 231 cells, as described in the human placenta (30), adipose tissue (31) and prostate cancer cell lines (32), we observed that exposure to recombinant adiponectin causes a significant down-regulation of its own receptors. For the first time, we found that AdipoR mRNA expression is down-regulated by leptin. This adipokine which is considered to be a potential contributing growth factor leading to the development of breast cancer acts directly or indirectly through increased local estrogen production (4). Thus, this down-regulation of adiponectin signaling by leptin observed in the present study may be an additional mechanism amplifying the mitogenic and proliferative effects of leptin towards mammary epithelial cells.

Experiments testing the direct effect of adiponectin on MDA-MB 231 cells showed significant cell growth inhibition which was not adiponectin dose-dependent. The same situation was also reported in MCF-7 and osteoblastic cells $(20,33)$. Thus, it cannot be excluded that the absence of adiponectin action on the cell number at concentrations $>25 \mathrm{ng} / \mathrm{ml}$ is due to the rapid down-regulation of AdipoR by adiponectin.

In order to gain further insight into the mechanisms whereby adiponectin exposure decreases MDA-MB 231 cell growth, we investigated cell cycle and apoptosis regulatory genes. These experiments demonstrated that adiponectin significantly reduces the expression of cyclin D1 and of the anti-apoptotic gene, $\mathrm{Bcl} 2$, and conversely induces the expression of the pro-apoptotic genes p53 and Bax. Under our experimental conditions, however, adiponectin treatment failed to induce DNA fragmentation, the last step of apoptosis. These findings, which are consistent with those of another study on the T47D cell line (28), are in contrast with those we recently reported in MCF-7 cells where adiponectin was found not only to induce pro-apoptotic genes but also enhance 
A
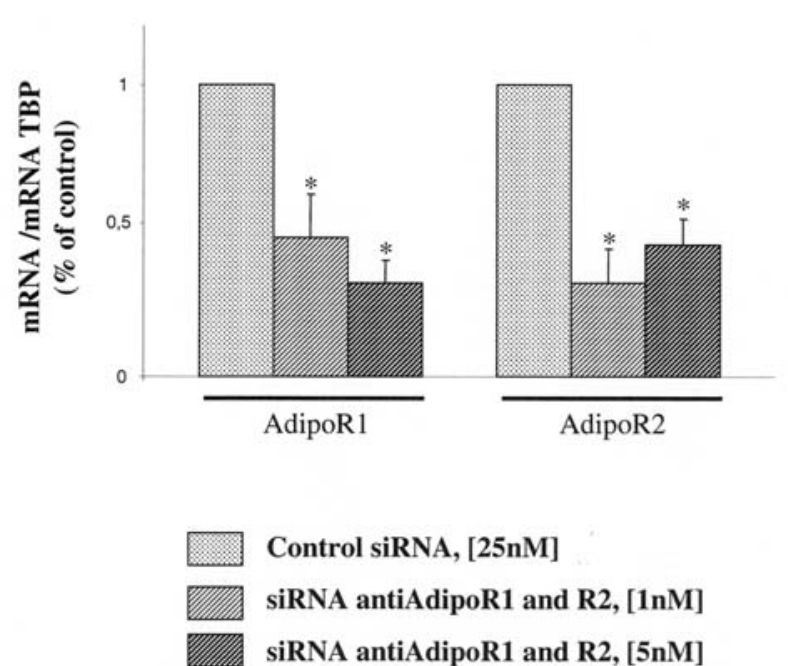

C

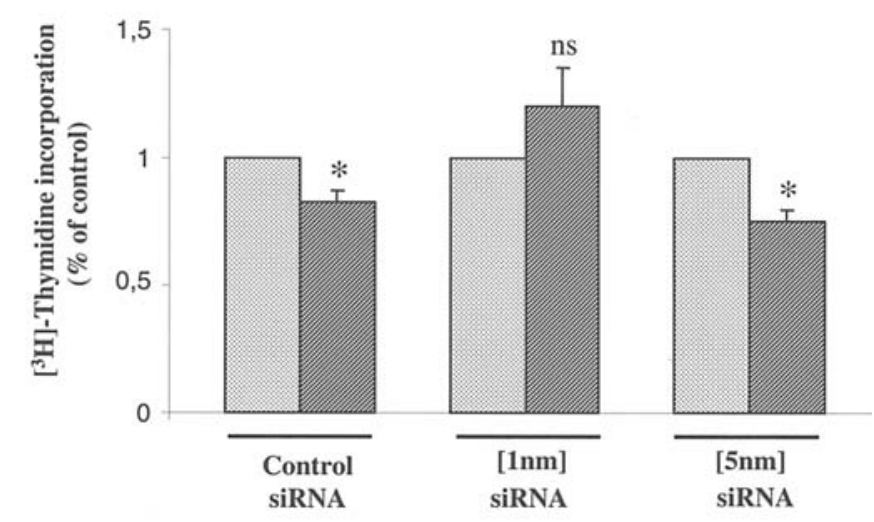

Control

Adiponectin $250 \mathrm{ng} / \mathrm{ml}$

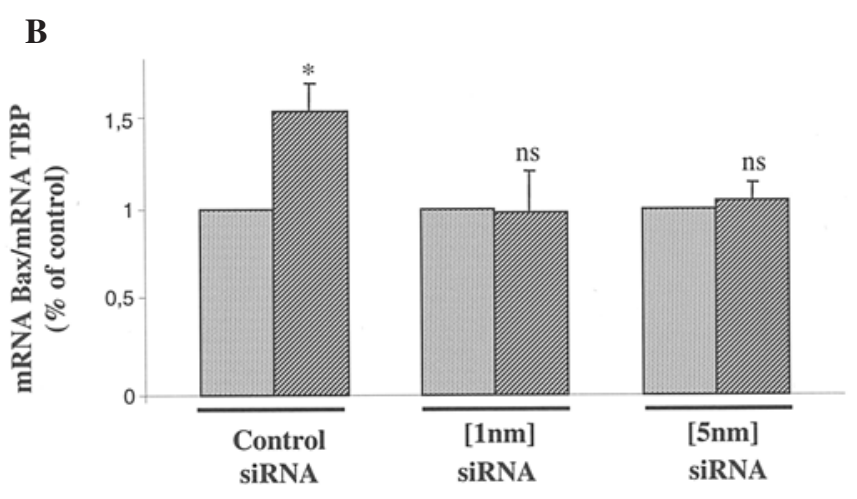

Control

Adiponectin $250 \mathrm{ng} / \mathrm{ml}$

Figure 5. Effects of adiponectin in AdipoR-deficient MDA-MB 231 cells. Cells were cultured for three days in the presence of $5 \mathrm{nM}$ AdipoR1/R2 or control siRNA. (A) Level of AdipoR in transfected cells. Total RNA was extracted and analyzed by RT-PCR. Results are the means \pm SEM of three experiments and are expressed as a percentage of the control (non-silencing). ${ }^{*} \mathrm{p}<0.05$; ns, non-significant, Wilcoxon test. (B) Effect on the adiponectin induction of Bax expression. AdipoR-depleted cells with $5 \mathrm{nM}$ of siRNA were or were not exposed to adiponectin $(25 \mathrm{ng} / \mathrm{ml})$ for $24 \mathrm{~h}$. Results are expressed as a percentage of the control (without adiponectin). Each bar represents the mean \pm SEM of four separate experiments; ${ }^{*} \mathrm{p}<0.05$; ns, nonsignificant, Wilcoxon test. (C) Effect on adiponectin-reduced DNA synthesis. AdipoR-depleted cells with 1 or $5 \mathrm{nM}$ of siRNA were or were not exposed to adiponectin $(25 \mathrm{ng} / \mathrm{ml})$ for $24 \mathrm{~h}$. Results are expressed as a percentage of the control (without adiponectin). Each bar is the mean \pm SEM of four separate experiments; ${ }^{*} \mathrm{p}<0.05$; ns, non-significant, Wilcoxon test.

DNA fragmentation (20). A possible explanation for these discrepancies is the variations in cell signaling between the cell lines or cell-specific effects of adiponectin on apoptosis. Several studies have reported a different response of the MDA-MB 231 and MCF-7 cell lines to different apoptotic agents including the soy isoflavone genistein (34). Moreover, the MCF-7 and MDA-MB 231 cells are distinguishable by their own characteristics: MCF-7 cells express functional ER, wild-type p53 and are caspase- 3 deficient, whereas MDA-MB 231 cells are ER-negative and express functional caspase-3 and mutant p53 $(35,36)$. The distinct apoptotic responses of MCF-7 and MDA-MB 231 cells to adiponectin are thus a novel illustration of the variability of mammary tumors in vivo and underline the complexity of breast cancer mechanisms.

As our data indicated that MDA-MB 231 cells expressed the two AdipoR, we investigated whether adiponectin affects these cells directly through AdipoR. Suppression of the two receptors by siRNA abolished adiponectin-induced proapoptotic Bax gene expression but not the adiponectinreducing effect on cell proliferation. These data suggest that adiponectin action on MDA-MB 231 cells is presumably, in part, mediated by AdipoR. Persistence of the adiponectin

anti-proliferative effect after a $70 \%$ invalidation of AdipoR raises the possibilities that $\mathrm{i}$ ) the $30 \%$ remaining receptors after invalidation are sufficient to mediate the adiponectin effects and/or ii) the action of adiponectin is mediated via alternative molecular/signaling pathways. Additional receptors for adiponectin have been described, such as T-cadherin (37). Experiments are currently in progress in our laboratory in order to determine the eventual implication of T-cadherin in adiponectin effects in MDA-MB 231 cells.

Adiponectin signal transduction may involve different pathways including AMP-, p42/p44 MAP-, PI3-, and p38 MAP kinases (38). We recently demonstrated the involvement of AMPK and the p42/p44 MAP kinase activations in the anti-proliferative action of adiponectin in MCF-7 cells (20). Thus complementary experiments will be needed to describe more precisely the pathways that mediate adiponectin effects in MDA-MB 231 cells.

In conclusion, our data indicate that adiponectin acts as an inhibitory growth factor in the ER-negative MDA-MB 231 cell line. Thus, in obese women, we can hypothesize that the decreased protective effects of adiponectin on mammary epithelial cell growth facilitated mitogenic effects of leptin. 
Hence, according to other in vitro studies, these two adipokines may be considered as molecular mediators linking adipose tissue to breast carcinogenesis, thereby constituting biomarkers for breast cancer risk in obese post-menopausal women.

\section{References}

1. Ballard-Barbash R, Schatzkin A, Carter CL, et al: Body fat distribution and breast cancer in the Framingham Study. J Natl Cancer Inst 82: 286-290, 1990.

2. Stephenson GD and Rose DP: Breast cancer and obesity: an update. Nutr Cancer 45: 1-16, 2003.

3. Housa D, Housova J, Vernerova Z and Haluzik M: Adipocytokines and cancer. Physiol Res 55: 233-244, 2006.

4. Ahima RS and Flier JS: Adipose tissue as an endocrine organ. Trends Endocrinol Metab 11: 327-332, 2000.

5. Lorincz AM and Sukumar S: Molecular links between obesity and breast cancer. Endocr Relat Cancer 13: 279-292, 2006.

6. Laud K, Gourdou I, Pessemesse L, Peyrat JP and Djiane J: Identification of leptin receptors in human breast cancer: functional activity in the T47-D breast cancer cell line. Mol Cell Endocrinol 188: 219-226, 2002.

7. Dieudonne MN, Machinal-Quelin F, Serazin-Leroy V, Leneveu MC, Pecquery R and Giudicelli Y: Leptin mediates a proliferative response in human MCF-7 breast cancer cells . Biochem Biophys Res Commun 293: 622-628, 2002.

8. Hu X, Juneja SC, Maihle NJ and Cleary MP: Leptin-a growth factor in normal and malignant breast cells and for normal mammary gland development. J Natl Cancer Inst 94: 1704-1711, 2002.

9. Arita Y, Kihara S, Ouchi N, et al: Paradoxical decrease of an adipose-specific protein, adiponectin, in obesity. Biochem Biophys Res Commun 257: 79-83, 1999.

10. Weyer C, Funahashi T, Tanaka S, et al: Hypoadiponectinemia in obesity and type 2 diabetes: close association with insulin resistance and hyperinsulinemia. J Clin Endocrinol Metab 86: 1930-1935, 2001.

11. Shimada K, Miyazaki $\mathrm{T}$ and Daida $\mathrm{H}$ : Adiponectin and atherosclerotic disease. Clin Chim Acta 344: 1-12, 2004.

12. Yamauchi $\mathrm{T}$, Kamon $\mathrm{J}$, Ito $\mathrm{Y}$, et al: Cloning of adiponectin receptors that mediate antidiabetic metabolic effects. Nature 423: 762-769, 2003.

13. Luo XH, Guo LJ, Yuan LQ, et al: Adiponectin stimulates human osteoblasts proliferation and differentiation via the MAPK signaling pathway. Exp Cell Res 309: 99-109, 2005.

14. Miyazaki T, Bub JD, Uzuki M and Iwamoto Y: Adiponectin activates c-Jun NH2-terminal kinase and inhibits signal transducer and activator of transcription 3. Biochem Biophys Res Commun 333: 79-87, 2005.

15. Ishikawa M, Kitayama J, Yamauchi T, et al: Adiponectin inhibits the growth and peritoneal metastasis of gastric cancer through its specific membrane receptors AdipoR1 and AdipoR2. Cancer Sci 98: 1120-1127, 2007.

16. Bub JD, Miyazaki T and Iwamoto Y: Adiponectin as a growth inhibitor in prostate cancer cells. Biochem Biophys Res Commun 340: 1158-1166, 2006.

17. Mantzoros C, Petridou E, Dessypris N, et al: Adiponectin and breast cancer risk. J Clin Endocrinol Metab 89: 1102-1107, 2004.

18. Miyoshi Y, Funahashi T, Kihara S, et al: Association of serum adiponectin levels with breast cancer risk. Clin Cancer Res 9: 5699-5704, 2003.

19. Kelesidis I, Kelesidis T and Mantzoros CS: Adiponectin and cancer: a systematic review. Br J Cancer 94: 1221-1225, 2006.
20. Dieudonne MN, Bussiere M, Dos Santos E, Leneveu MC, Giudicelli Y and Pecquery R: Adiponectin mediates antiproliferative and apoptotic responses in human MCF7 breast cancer cells. Biochem Biophys Res Commun 345: 271-279, 2006.

21. Gorka M, Godlewski MM, Gajkowska B, Wojewodzka U and Motyl T: Kinetics of Smac/DIABLO release from mitochondria during apoptosis of MCF-7 breast cancer cells. Cell Biol Int 28: 741-754, 2004.

22. Bradford MM: A rapid and sensitive method for the quantitation of microgram quantities of protein utilizing the principle of protein-dye binding. Anal Biochem 72: 248-254, 1976.

23. Machinal-Quelin F, Dieudonne MN, Leneveu MC, Pecquery R and Giudicelli Y: Proadipogenic effect of leptin on rat preadipocytes in vitro: activation of MAPK and STAT3 signaling pathways. Am J Physiol Cell Physiol 282: C853-C863, 2002.

24. Garofalo C and Surmacz E: Leptin and cancer. J Cell Physiol 207: 12-22, 2006

25. Mawson A, Lai A, Carroll JS, Sergio CM, Mitchell CJ and Sarcevic B: Estrogen and insulin/IGF-1 cooperatively stimulate cell cycle progression in MCF-7 breast cancer cells through differential regulation of c-Myc and cyclin D1. Mol Cell Endocrinol 229: 161-173, 2005.

26. Prall OWJ, Rogan EM, Musgrove EA, Watts CKW and Sutherland RL: c-Myc or cyclin D1 mimics estrogen effects on cyclin E-Cdk2 activation and cell cycle re-entry. Mol Cell Biol 18: 4499-4508, 1998.

27. Arditi JD, Venihaki M, Karalis KP and Chrousos GP: Antiproliferative effect of adiponectin on MCF7 breast cancer cells: a potential hormonal link between obesity and cancer. Horm Metab Res 39: 9-13, 2007.

28. Korner A, Pazaitou-Panayiotou K, Kelesidis T, et al: Total and high-molecular-weight adiponectin in breast cancer: in vitro and in vivo studies. J Clin Endocrinol Metab 92: 1041-1048, 2007.

29. Rasmussen MS, Lihn AS, Pedersen SB, Bruun JM, Rasmussen M and Richelsen B: Adiponectin receptors in human adipose tissue: effects of obesity, weight loss, and fat depots. Obesity 14: 28-35, 2006

30. Caminos JE, Nogueiras R, Gallego R, et al: Expression and regulation of adiponectin and receptor in human and rat placenta. J Clin Endocrinol Metab 90: 4276-4286, 2005.

31. Bauche IB, Ait El Mkadem S, Rezsohazy R, et al: Adiponectin downregulates its own production and the expression of its AdipoR2 receptor in transgenic mice. Biochem Biophys Res Commun 345: 1414-1424, 2006.

32. Mistry T, Digby JE, Chen J, Desai KM and Randeva HS: The regulation of adiponectin receptors in human prostate cancer cell lines. Biochem Biophys Res Commun 348: 832-838, 2006.

33. Berner HS, Lyngstadaas SP, Spahr A, et al: Adiponectin and its receptors are expressed in bone-forming cells. Bone 35: 842-849, 2004.

34. Yang S, Zhou Q and Yang X: Caspase-3 status is a determinant of the differential responses to genistein between MDA-MB231 and MCF-7 breast cancer cells. Biochim Biophys Acta 1773: 903-911, 2007.

35. Li Y, Upadhyay S, Bhuiyan M and Sarkar FH: Induction of apoptosis in breast cancer cells MDA-MB-231 by genistein. Oncogene 18: 3166-3172, 1999.

36. $\mathrm{Xu} \mathrm{J}$ and Loo G: Different effects of genistein on molecular markers related to apoptosis in two phenotypically dissimilar breast cancer cell lines. J Cell Biochem 82: 78-88, 2001.

37. Hug C, Wang J, Ahmad NS, Bogan JS, Tsao TS and Lodish HF: $\mathrm{T}$-cadherin is a receptor for hexameric and high-molecularweight forms of Acrp30/adiponectin. Proc Natl Acad Sci USA 101: 10308-10313, 2004.

38. Kadowaki $\mathrm{T}$ and Yamauchi T: Adiponectin and adiponectin receptors. Endocr Rev 26: 439-451, 2005. 